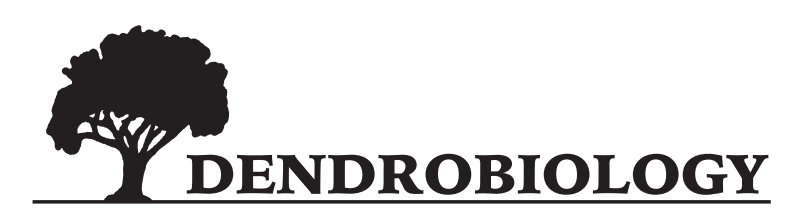

2014, vol. 71, 137-148

http://dx.doi.org/10.12657/denbio.071.014

\author{
Md. Aktar Hossain, Jebin Ferdous, M. Abdur Rahman, \\ Md. Abul kalam Azad, Nor Aini Ab. Shukor
}

\title{
Towards the propagation of a critically endangered tree species Anisoptera scaphula
}

\author{
Received: 19 April 2013; Accepted 09 September 2013
}

\begin{abstract}
Anisoptera scaphula (Roxb.) Kurz, the tallest tree species in Bangladesh, is critically endangered worldwide due to its poor natural regeneration. This study describes the appropriate regeneration technique for $A$. scaphula through seed germination and clonal propagation by stem cutting. The fastest and highest germination percentage (65) was observed in dewinged seeds sown inverted orientation with half buried position (T10) followed by dewinged seeds (62.5\%) sown horizontally in full buried (T7) and delayed germination with lowest percentage (15) was in control (T0). Optimum initial growth was also shown when seedlings were developed from the seeds under T7. Both winged and dewinged seeds sown vertically in full buried or half buried position produced curved seedlings. However, dewinged seeds sown in horizontal or inverted (winged side down) position produced otherwise i.e., straight seedlings. The highest rooting percentages $(63 \%)$ and maximum number of root (4.8) per cutting were obtained when one node cuttings treated with $0.8 \%$ IBA solution followed by $0.4 \%$ IBA in turn affecting for better survival and growth of rooted cuttings in the nursery conditions.
\end{abstract}

Additional key words: Dipterocarpaceae, seed orientation, sowing position, germination percentage, rooting ability.

Addresses: M.A. Hossain, N.A.A. Shukor, Faculty of Forestry, Universiti Putra Malaysia, 43400 UPM, Serdang, Selangor D.E, Malaysia, email: aktar_forestry@hotmail.com

M.A. Hossain, J.Ferdous, M.A.K. Azad, Institute of Forestry and Environmental Sciences, Chittagong University, Chittagong - 4331, Bangladesh

M.A. Rahman Assistant Conservator of Forests, Institute of Forest Science and Technology, Rajshahi, Bangladesh

N.A.A. Shukor, Institute of Tropical Forestry and Forest Product, Universiti Putra Malaysia, 43400 UPM, Selangor D.E, Malaysia.

\section{Introduction}

Bangladesh is a South Asian country that lies between $20^{\circ} 34^{\prime}$ and $26^{\circ} 38^{\prime} \mathrm{N}$ latitude and $88^{\circ} 01^{\prime}$ and $92^{\circ} 41^{\prime} \mathrm{E}$ longitude (FAO 2009) enjoys a typical mon- soon climate. Plenty of rainfall $(3000 \mathrm{~mm})$ with hot humid temperature blessed the southeastern part of the country (Chittagong, Chittagong Hill Tract and Cox's Bazar) with continuous high forests and many biodiversity hotspots composed of wide range of timber species. About 500 timber species grow in Bang- 
ladesh (Sattar and Akhtaruzzaman 1997; Banglapedia 2012) among them, Anisoptera scaphula (Family: Dipterocarpaceae) is the tallest, usually evergreen and often slightly buttressed with long cylindrical bole (Fig. 1). The wood of this species is hard, rigid and durable, pale yellowish to pale brown, takes good polish, suitable for furniture making, construction works, house building, boat building and many other commercial purposes (Das and Alam 2001). Fruits are winged nuts (around $1.6 \mathrm{~cm}$ in diameter), fruiting calyx tube is much constricted at the mouth, wings are oblanceolate, $11-17 \mathrm{~cm}$ long, and $1.5-2.5 \mathrm{~cm}$ wide with three prominent longitudinal veins joined at right angles by conspicuous transverse veins (Fig. 1). The genera Anisoptera consists of ten species distributed from Chittagong (Bangladesh) to New Guinea including Malaysia, Myanmar, Thailand and Vietnam (Ashton 2005). Eight out of the ten species under the genera are currently listed in the IUCN Red List (four species listed as critically endangered while others are considered endangered). Out of the four critically endangered species in the genera, $A$. scaphula is at the highest risk of extinction (IUCN 2012). The species is native to Bangladesh and known to grow in small pockets in Chittagong, Chittagong Hill Tract and Cox's Bazar forest areas. However, currently the species is restricted only in Saplapur and Silkhali beats of the Cox's Bazar South Forest Division. The main threats of this species are habitat loss, absence of mother trees for seed production and poor natural regeneration (Ashton 1998). Moreover, the seeds are recalcitrant and cannot be stored for a long time. The fruits of this species consist of long wings that prevent the seeds from settling properly on soil for germination. The seed germination usually starts with developing the radicle from the wing side and later, plumule from the stalk end. Therefore, development of appropriate seed germination technique might be one of the biggest challenges to achieve the artificial regeneration of the species. Several studies have reported that seed orientation and sowing position significantly affect the germination and seedling growth attributes in many forest species (Prasad and Nautiyal 2003). For instances, Bosy and Aarssen (1995) reported reduced germination in inverted seeds compared to that in other orientations while Pandey and Khatoon (1999) estimated $80 \%$ germination in Sterculia urens seeds sown in vertical position at $2 \mathrm{~cm}$ and horizontal position at $4 \mathrm{~cm}$ depth. Maximum germination $(80 \%)$ of Calamus prasinus seeds was recorded in inverted orientation while C. stoloniferus and C. thwaitesii seeds in vertical orientation (Bhat 2011). Again, Elfeel (2012) noted that the best germination of Balanites aegyptiaca seeds was observed in horizon-

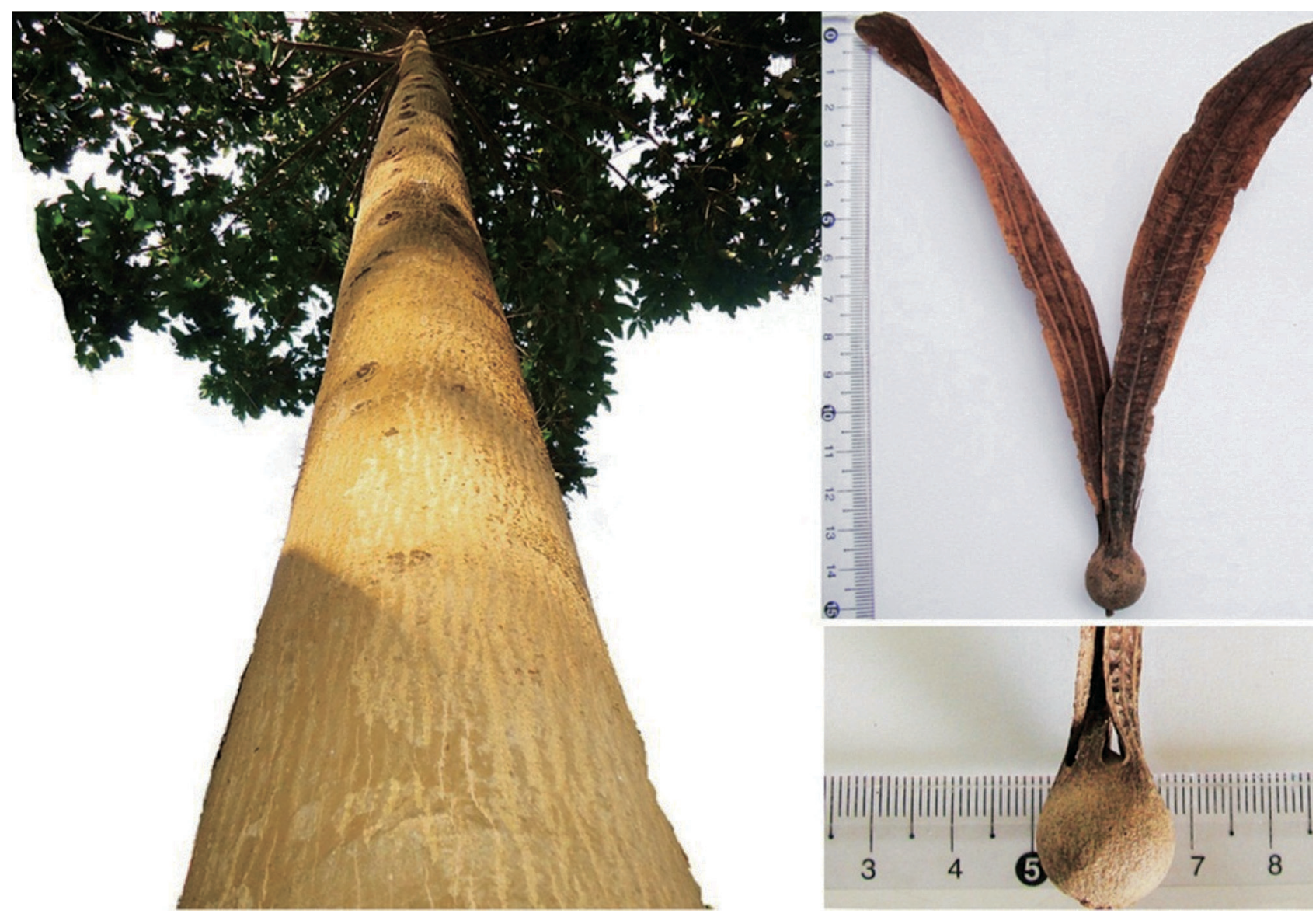

Fig. 1. A 20-year old tree and fruit of Anisoptera scaphula 
tal and vertical orientations. However, Bennet-Clarck et al. (1959) suggested that the inversion of seedling might bring to abnormal chemical or physical changes which in turn manifest abnormal morphological developments. Natural growth directions of plumule and radicle would therefore be ensured by suitable orientation and sowing position of seed for better germination and survival of seedlings.

The seedling growth and morphology of many Dipterocarpus species is also known to be affected significantly by the growth light environments (Ashton 1995; Whitmore and Brown 1996; Ashton et al.1997; Barker et al. 1997). Most of these studies reported better growth of Dipterocarp seedlings in partial shade or in moderate light intensity. However, there was no study that described how the pre-sowing treatments would affect the seed germination and seedling structure and light intensities on the seedling growth attributes of $A$. scaphula.

On the other hand, over exploitation due to illegal felling destroyed the seed trees almost completely. Moreover, the species does not bear seeds every year (Krishnapillay and Tompsett 1998) or are consistently a bad producer of seeds. The ripening time is also very short, and hence any delay in seed collection causes complete loss of the seeds. This problem with seeds and their collection makes supply of sufficient seeds for plantation programs difficult. Hence the lack of sufficient quantity of quality seeds and seedlings invariably leads to a failure of establishing a large scale plantation program. However, clonal propagation technique can solve many of these problems (Kamaluddin, 1988). The technique allows production of large and continuous supply of planting stocks together with capturing and multiplying genetic variations. This when coupled with technique to select superior individuals can result in large genetic gain in both yield and quality. Vegetative propagation through stem cutting is an important alternative for production of high quality uniform planting stocks for a large scale reforestation purposes. Stem cutting is inexpensive and easier to practice than other vegetative propagation methods like tissue culture. It can maintain continuous supply of planting stock throughout the year for reforestation programs. Although vegetative propagation by stem cuttings has been reported as an alternative method of supplying planting materials of Dipterocarps in many studies (Halle and Hanif-Kamil 1981; Smits 1983, 1986; Hamzah 1990a, b, c; Kantarli 1993a, b), it is considered to be very difficult to root (Chouffot-Struycken 1986). Therefore, various rooting hormones have been used to increase the rooting ability of desired cuttings. Rooting response can be substantially improved by applying exogenous rooting hormone IBA, which has already been observed in Eucalyptus (Fett-Neto et al. 2001), Artocarpus heterophyllus (Hossain et al. 2002), Pausinystalia johimbe (Tchoundjeu et al. 2004), Baccaurea sapida (Abdullah et al. 2005), Stereospermum suaveolens (Baul et al. 2009), and Flacourtia jangomas (Hossain et al. 2011) However, the published knowledge base about the clonal propagation technique of $A$. scaphula is very limited and yet to publish. We therefore, designed the present research work aiming to develop a complete protocol for raising nursery from seeds using various seed orientations and sowing positions and clonal propagations from stem cuttings of the species with various concentration of IBA solution.

\section{Materials and Methods}

The study was carried out over a period of two years in the nursery of the Institute of Forestry and Environmental Sciences, Chittagong University, Bangladesh. The climate of the area is typically tropical monsoon, characterized by hot humid summer and cool dry winter (BBS 2010). Mean annual rainfall in the area is around 3,000 $\mathrm{mm}$ (Banglapedia 2012). The study was conducted in three different phases: i) determination of the effects of dewinging, seed orientation and sowing position on germination and seedling growth attributes, ii) assessment of seedling growth performance under various light conditions and iii) development of clonal propagation technique through stem cutting.

\section{Seed collection, pre-sowing treatments and experimental design}

Seeds of A. scaphula were collected in May 2011 from Saplapur beat of the Cox's Bazar South Forest Division. Seeds of uniform size were sorted and used for the germination trials to reduce non treatment variations since germination and seedling vigor are positively correlated to seed size (Gunaga et al. 2007; Gunaga et al. 2011). Around half of the seeds sorted were dewinged. Then both winged and dewinged seeds were sown in the polybags filled with forest soil (having $\mathrm{pH}$ 5.0) mixed with decomposed cowdung at a ratio of 3:1 under 11 separate treatments. The treatments were control i.e., winged seeds placed on the moist soil as found in the forest floor (T0), winged seeds sown vertically (winged side up) in full (T1) or half (T2) buried position, horizontally in full (T3) or half (T4) buried position, dewinged seeds sown vertically in full (T5) or half (T6) buried position, horizontally in full (T7) or half (T8) buried position, inverted (wing side down) in full (T9) or half (T10) buried position (Fig. 2). Randomized Complete Block Design (RCBD) with three replications per treatment was adopted for the experiment to determine seed germination performance and seedling growth. Each replication consisted of 30 and each 

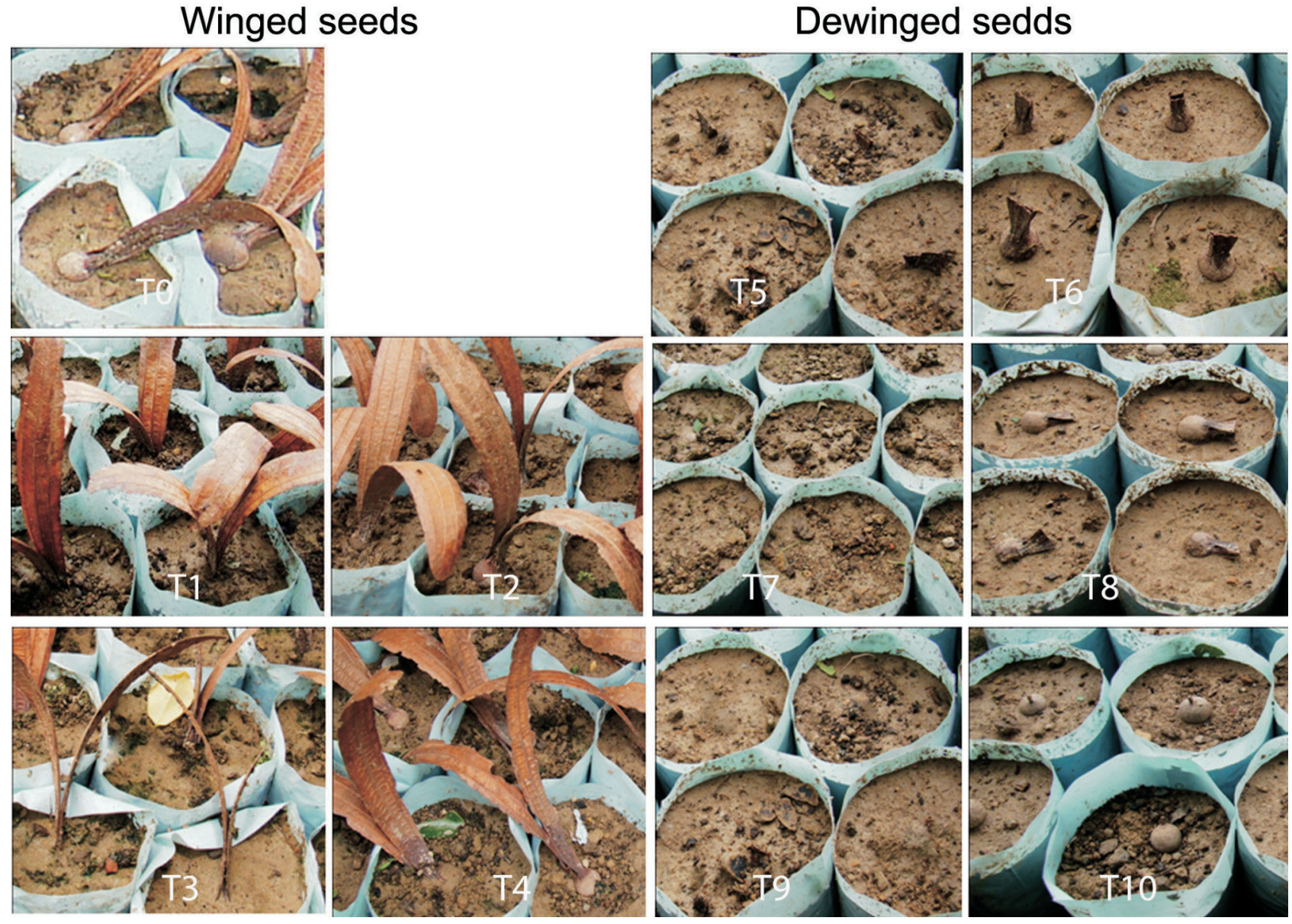

Fig. 2. Dewinging, seed orientations and sowing position of $A$. scaphula seeds. T0 = control (winged seeds placed on moist soil as seen on forest floor); winged seeds sown vertically in full (T1) or half (T2) buried position and horizontally in full (T3) or half (T4) buried position. Dewinged seeds sown vertically in full (T5) or half (T6) buried, horizontally in full (T7) or half (T8) and inverted in full (T9) or half buried (T10) position

treatment of 90 seeds and a total of 990 seeds were subjected to eleven different pre-sowing treatments for the experiment. From the time of sowing seeds to the harvesting of seedlings, watering was done every morning and weeding was done every third day. No fertilizer or insecticide or pesticide was applied during this study.

\section{Seed germination and seedling growth records}

From the date of sowing the seeds, germination percentages were recorded for different treatments and it was continued until the germination ceased. The seed germination criterion was visible on the surface of soil at least $0.5 \mathrm{~cm}$ of the cotyledon and hypocotyls of the seedlings. Daily germination was summed up to obtain cumulative germination percentage for each treatment. The total germination period was recorded for each treatment. Germination percentage was determined with following formula:

$$
\mathrm{GP}=\frac{N S G}{N S S} \times 100 \%
$$

where: GP - germination percentage; NSG - number of seed germinated; NSS - number of seed sown.

\section{Seedlings form and growth performance}

The shape and growth performance of seedlings developed from various sowing position and orientations were assessed six months after sowing the seeds. The height and collar diameter were measured for all seedlings in the treatments. Due to lack of sufficient number of seedlings developed from T0, the treatment was limited to germination trial only and excluded from the growth performance examination. 


\section{Growth performance of seedlings under different light conditions}

The seedlings which attaining height of $15-20 \mathrm{~cm}$ six months after sowing the seeds and growing in full sun, were placed under three light regimes: full sun (FS), partial shade (PS) and deep shade (DS) to determine the optimum light conditions for the growth and development of seedlings. In the FS the seedlings experienced around 22 mol photon flux $\mathrm{m}^{-2} \mathrm{day}^{-2}$. Compared to the FS, the stock plants received about $60 \%$ daylight in the PS and about $10 \%$ daylight in the DS regime. The PS regime allowed direct sunlight in the form of sun patch and sun flecks. In each light condition 60 seedlings were placed and allowed to grow for three months. The height and collar diameter were then measured for all seedlings in each light regime. Ten seedlings from each light regime were randomly uprooted and the shoot length, root length and total length were measured. The leaves, shoots and roots were separated and dried in electrical oven at $72^{\circ} \mathrm{C}$ for $48 \mathrm{~h}$ to assess the dry weight for determining their growth performance under various light conditions.

\section{Clonal propagation through stem cutting}

\section{Shoot collection and cutting preparation}

Juvenile shoots were collected from 1-year old stockplants grown in partial shade in nursery orchard (Hossain and Kamaluddin 2004, 2005). The stockplants were decapitated prior to shoot collection for facilitating the development of numerous juvenile shoots for cutting. One-node cuttings with two leaves trimmed to one third were prepared from the juvenile shoots collected from the decapitate stockplants. Cutting length and diameter in all treatments were kept indifferent to avoid the non-treatment variations among the treatments.

\section{IBA treatment and planting in the non-mist propagator}

The cuttings were immersed briefly in a solution of fungicide, Diathane M45 (2 $\left.\mathrm{gL}^{-1}\right)$ to avoid fungal infection and kept under shade for 10 minutes in open air. Cuttings were then treated with $0 \%, 0.2 \%$, $0.4 \%, 0.8 \%$ indole 3 -butyric acid (IBA) solution for one minute to explore the effects of IBA on rooting ability of cuttings. Cuttings were then planted in perforated plastic trays $(12 \mathrm{~cm}$ depth) filled with coarse sand mixed with fine gravel and placed into non-mist propagator (Kamaluddin 1996) for rooting. RCBD was followed with three replications (20 cuttings each) for each treatment. Thus, the number of replicate cutting for each treatment was 60 and the total number of cuttings was 240 . The experiment was repeated three times to confirm the reproducibility of the methods.

\section{Watering and weaning}

The cuttings were watered once only just after setting into the propagator. The propagator was opened briefly in early morning and late afternoon every day to facilitate gas diffusion and a light spray of water until transferring the rooted cuttings from the propagator. The cuttings that rooted twelve weeks after setting them into the propagator were subjected to wean before transferring them into polybags. For plant hardening, the propagator was kept open at night for three consecutive days and at day and night for another three days.

\section{Transferring rooted cuttings into polybags}

After weaning, all the rooted cuttings were uprooted and transferred to polybags filled with soil and decomposed cow dung at a ratio of 3:1. Before planting into polybags, rooted cuttings were measured for length and diameter. Rooting percentage, number of root developed in each cutting and the length of the longest root was also recorded for each treatment.

To determine the steckling capacity (ability to survive), of the rooted cuttings after transferring into polybags, transplanted polybags were kept in shade for a week before placing them in the sun for normal growth. After four months, the initial growth performance of the rooted cuttings was assessed by measuring total height, collar diameter and leaf number for all rooted cuttings. Analysis of variance (ANOVA) and Duncan Multiple Range Test (DMRT) were performed to explore the possible difference among the treatments.

\section{Results and Discussion}

\section{Seed orientation and sowing position}

\section{Germination percentage}

Germination percentage of $A$. scaphula seeds was significantly affected by dewinging, seed orientations and sowing position. Germination percentage varied from 15 to 65 among the treatments. The highest germination percentage (65) was obtained in T10 followed by $62.5 \%$ in T7. The lowest germination percentage (15) was observed in T0 (control) (Fig. 3a). In a similar study on Scaphula glabra, Laurie (1940) reported low germination (40\%) when seeds were buried $2.54 \mathrm{~cm}$ to $3.84 \mathrm{~cm}$ deep in slanting position and higher germination $(66 \%)$ when seeds were sown superficially at $0.64 \mathrm{~cm}$ depth with the apex downward and the stalk-end upward. Bhat (2011) estimated maximum germination $(80 \%)$ of Calamus prasinus seeds in inverted orientation while C. stoloniferus and C. thwaitesii seeds in vertical orientation. However, Pandey and Khatoon (1999) recorded highest germination (80\%) in Sterculia urens seeds sown in vertical position at $2 \mathrm{~cm}$ and horizontal position 

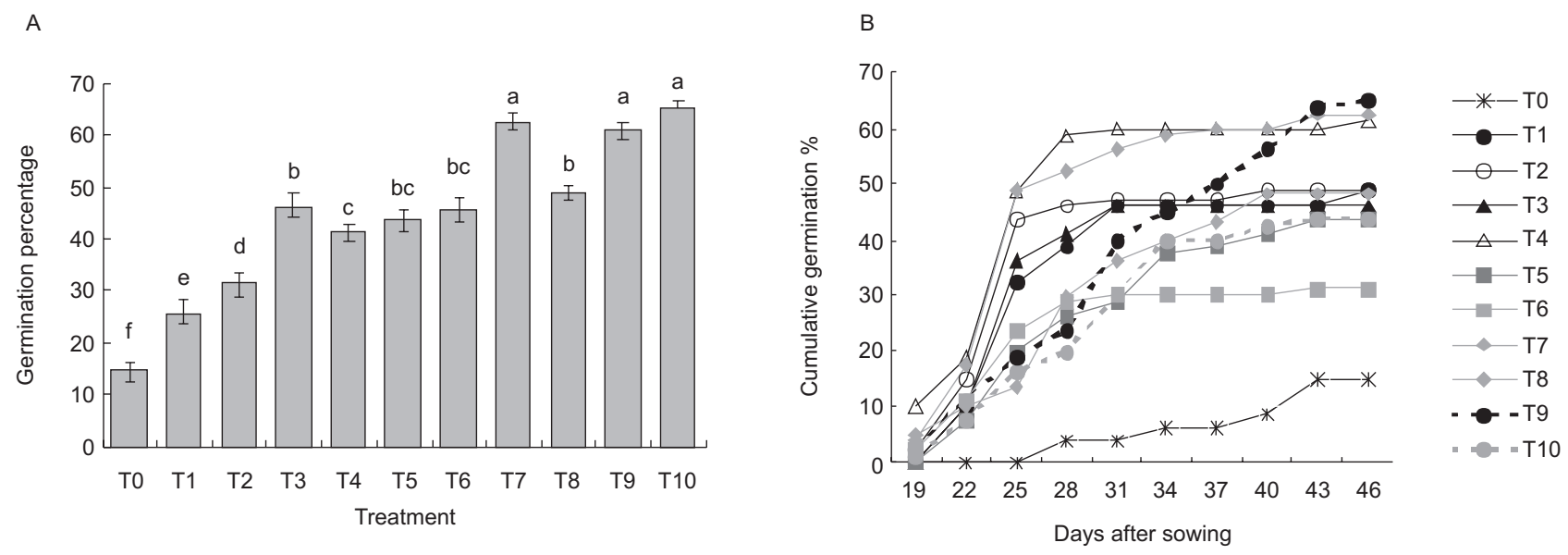

Fig. 3. Germination percentage (A) and pattern (cumulative germination percentage) (B) of A. scaphula seeds under different seed orientations and sowing positions. Note: the same letter(s) indicates no significant difference at $p \leq 0.05$, according to Duncan's Multiple Range Test. I (error bar) indicates the standard error of means

at $4 \mathrm{~cm}$ depth. Elfeel (2012) also noted that the best germination of Balanites aegyptiaca seeds observed in horizontal and vertical orientations.

\section{Germination period}

Seed germination started two days after sowing and continued up to 10 days. The fastest germination (least imbibition period; two days) was observed in T8 (dewinged seeds sown horizontally in half buried position) and T10 and delayed (highest imbibition period, 10 days) was observed in T0 (control, winged seeds placed on the moist soil similar as is found in the forest floor) (Table 1). Germination started with the development of radicle from the winged side of the seed. That is why the radicles were seen early when the seeds were sown vertically or horizontally in half buried position. The seeds sown inverted might have radicle earlier but were not visible beneath the soil surface. The result of this study was in line with Banik (1980) which reported early germination of Dipterocarpus turbinatus was determined equally when seeds were sown in half-buried position and delayed germination when seeds were completely buried.

\section{Germination patterns, seedling structure and growth performance}

The cumulative germination percentages in $\mathrm{T} 2$, $\mathrm{T} 3$ and $\mathrm{T} 8$ rose sharply from day 19 until day 25 and remained constant up to day 46 (Fig. 3b). In most of the orientations and sowing positions, the germination percentages rose sharply up to the day 31 . Germination of the seed was hypogenous where radicle emerged by breaking through the dome-shaped structure of seed and moved downwards rapidly (Fig. 4). Thus when the seeds were sown vertically the radicle started to grow upward first and moved downward later by making a curve. However, when the seeds were sown horizontally the radicle started to grow sideward (horizontally) and moved downward by making slight curve and grew straight downward when the seeds sown inverted (Fig. 5).

The seed orientation and sowing position in soil greatly affected the seedling structure was observed six months after sowing the seeds. Both winged and dewinged seeds produced deformed seedlings, mostly crooked, when they were sown vertically in full buried position (Fig. 6). When they were sown vertically in half buried position the seedling shape was slightly better than those were from full buried seeds. The seedlings showed a slight deformation when they were grown from winged seeds sown horizontally in full buried or half buried position. Dewinged seeds sown horizontal or inverted (winged side down) orientation grew into straight seedlings without any curl or deformity (Fig. 6 and supplementary data 1). Similar result was reported by Laurie (1940)

Table 1. Effects of seed sowing position on germination period of $A$. scaphula. Note: Same letter(s) in the same row indicates no significant difference at $p \leq 0.05$, according to Duncan's Multiple Range Test. \pm indicates the standard error of means

\begin{tabular}{|c|c|c|c|c|c|c|c|c|c|c|c|c|}
\hline \multirow{2}{*}{ Variable } & \multicolumn{11}{|c|}{ Treatment } & \multirow[b]{2}{*}{$\mathrm{p}$} \\
\hline & T0 & $\mathrm{T} 1$ & $\mathrm{~T} 2$ & T3 & $\mathrm{T} 4$ & T5 & T6 & T7 & T8 & T9 & T10 & \\
\hline $\begin{array}{l}\text { Germination } \\
\text { starting(days) }\end{array}$ & $\begin{array}{l}10.0 \pm \\
2.7^{c}\end{array}$ & $\begin{array}{l}7.0 \pm \\
0.6^{\mathrm{bc}}\end{array}$ & $\begin{array}{l}4.67 \pm \\
0.7^{\mathrm{ab}}\end{array}$ & $\begin{array}{l}6.0 \pm \\
1.7^{\mathrm{ab}}\end{array}$ & $\begin{array}{l}4.3 \pm \\
0.9^{\mathrm{ab}}\end{array}$ & $\begin{array}{l}4.33 \pm \\
1.2^{\mathrm{ab}}\end{array}$ & $\begin{array}{l}4.33 \pm \\
0.9^{\mathrm{ab}}\end{array}$ & $\begin{array}{l}3.67 \pm \\
0.7^{\mathrm{ab}}\end{array}$ & $\begin{array}{l}2.67 \pm \\
0.3^{\mathrm{a}}\end{array}$ & $\begin{array}{l}3.33 \pm \\
1.3^{\mathrm{ab}}\end{array}$ & $\begin{array}{l}2.67 \pm \\
0.7^{a}\end{array}$ & .013 \\
\hline $\begin{array}{l}\text { Germination } \\
\text { ending (days) }\end{array}$ & $\begin{array}{l}28.0 \pm \\
1.5^{\mathrm{def}}\end{array}$ & $\begin{array}{c}34.7 \pm \\
2.4^{\mathrm{g}}\end{array}$ & $\begin{array}{l}32.0 \pm \\
1.25^{\mathrm{fg}}\end{array}$ & $\begin{array}{c}28.6 \pm \\
1.7^{\mathrm{ef}}\end{array}$ & $\begin{array}{l}27.0 \pm \\
1.5^{\mathrm{cde}}\end{array}$ & $\begin{array}{l}23.6 \pm \\
1.9^{\mathrm{abcd}}\end{array}$ & $\begin{array}{r}23.6 \pm \\
0.9^{\mathrm{abcd}}\end{array}$ & $\begin{array}{c}24.6 \pm \\
0.3^{\text {bcde }}\end{array}$ & $\begin{array}{c}23.0 \pm \\
1.5^{\mathrm{abc}}\end{array}$ & $\begin{array}{c}21.3 \pm \\
1.8^{\mathrm{ab}}\end{array}$ & $\begin{array}{c}19.0 \pm \\
0.6^{\mathrm{a}}\end{array}$ & .000 \\
\hline
\end{tabular}


that seeds of Scaphula glabra sown with the wings upwards have the radicle twisted and curled and many die back before they can enter the soil; causing a high percentage of casualties and the survivors are badly
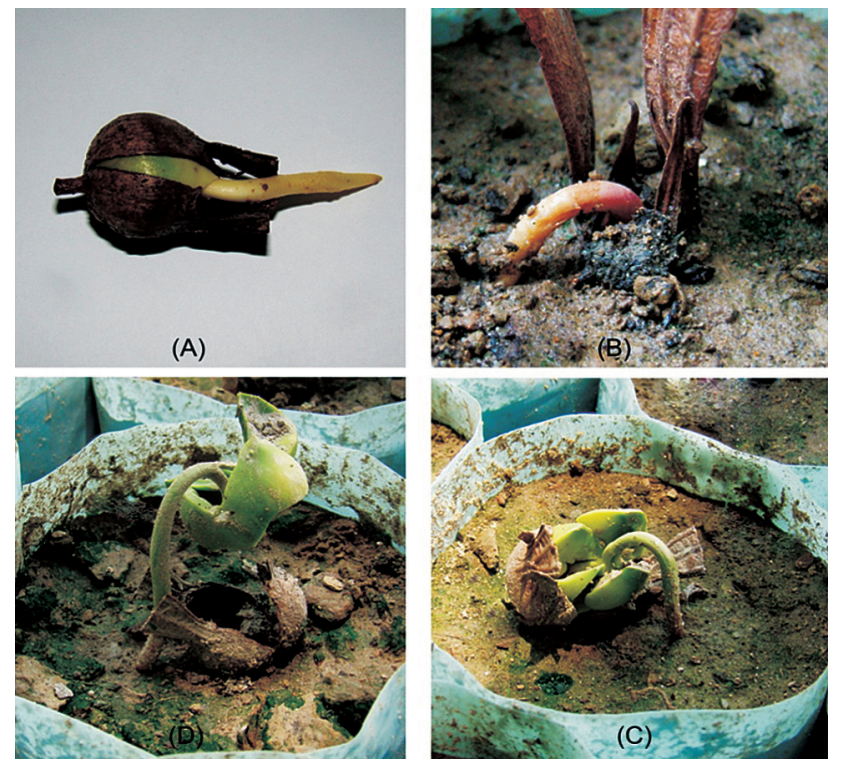

Fig. 4. Various stages of $A$. scaphula seed germination. A) Initiation of radicle from the wing side, B) penetration of root in soil, C) bursting out of seed coat and D) cotyledons throw off seed coat
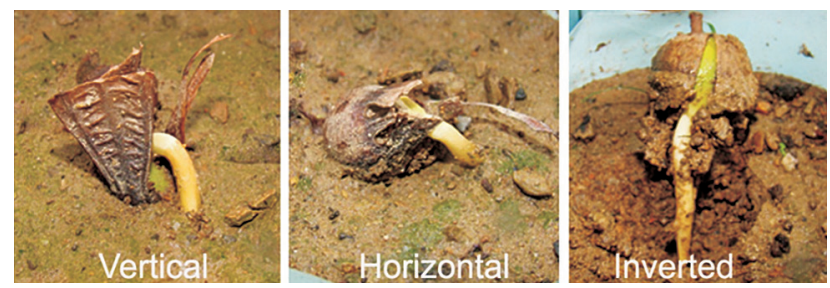

Fig . 5. Germination pattern of seeds sown in vertical, horizontal and inverted position in soil contorted. However, clipping the wings and sowing the seeds upside-down produced higher percentage of germination and good survival of seedlings with stronger and straighter in shape. Banik (1980) also showed that sowing position of Dipterocarpus seeds affects germination period, germination percentage and sometimes the seedling shape. Seedling growth parameters like height and collar diameter were also greatly influenced by the seed orientation and sowing position. The highest average height $(22.4 \mathrm{~cm})$ of the seedlings was found in T7 followed by $21.9 \mathrm{~cm}$ in T6 and the lowest $(9.8 \mathrm{~cm})$ was in T0 (control). The collar diameter of the seedlings was also maximum $(0.56 \mathrm{~cm})$ in $\mathrm{T} 7$ followed by $0.54 \mathrm{~cm}$ in $\mathrm{T} 3$ and the lowest $(0.37 \mathrm{~cm})$ was in T0 (Fig. 7$)$.

\section{Growth performance under different light conditions}

Seedling morphology like shoot length, and total length of seedlings substantially varied in different light regimes. However, there was no remarkable variation in the mean root length of the seedlings grown under different light conditions. Due to significant difference in shoot length, total length of the seedlings also varied meaningfully. The mean total length of the seedling was found highest $(43.67 \mathrm{~cm})$ in PS and the lowest $(26.17 \mathrm{~cm}$ ) in DS (Fig. 8). The dry mass of the seedling components (leaf, shoot, root) were also greatly affected by the light regimes. The maximum dry weight of shoot $(2.3 \mathrm{~g})$ and root $(1.8 \mathrm{~g})$ was observed in the seedlings grown in PS but maximum dry weight of leaf (4.83 g) was in FS. Total dry weight was maximum $(9.03 \mathrm{~g})$ in PS and minimum in the DS regime (Fig. 8). PS enhanced the growth of the A. scaphula seedlings in the present study. The relationship between Dipterocarp seedling growth performance and light availability were examined in

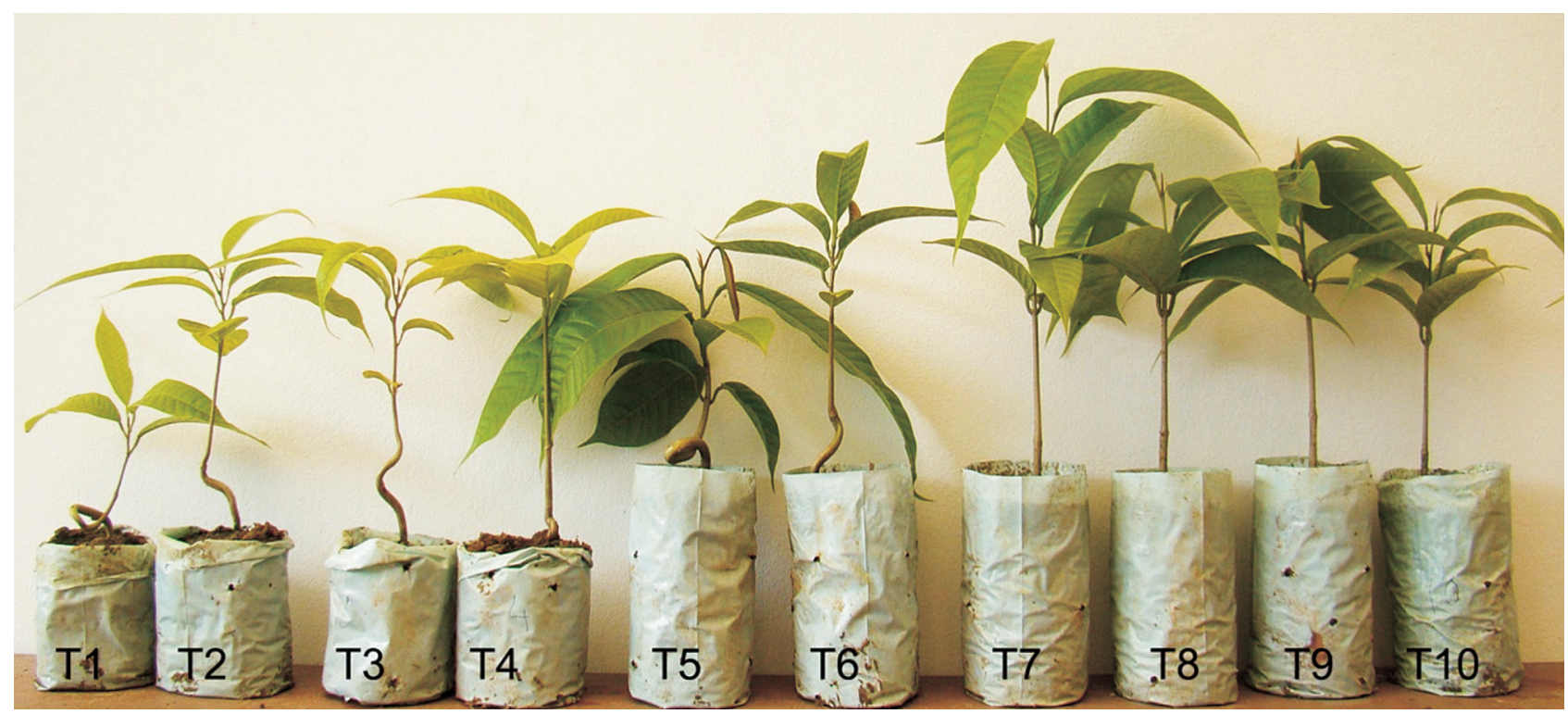

Fig. 6. Seedlings raised from seeds with different pre-sowing treatment and sowing positions 

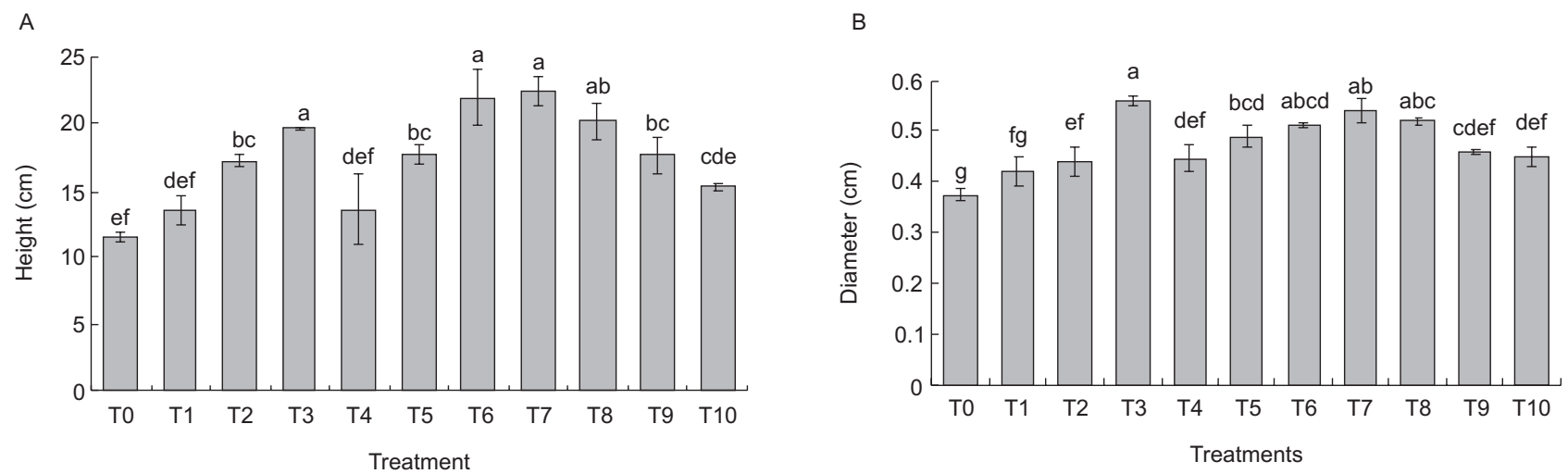

Fig. 7. Height (A) and diameter (B) growth of seedlings germinated under various seed orientations and sowing position. Note: The same letter(s) indicates no significant difference at $p \leq 0.05$, according to Duncan's Multiple Range Test. I (error bar) indicates the standard error of means
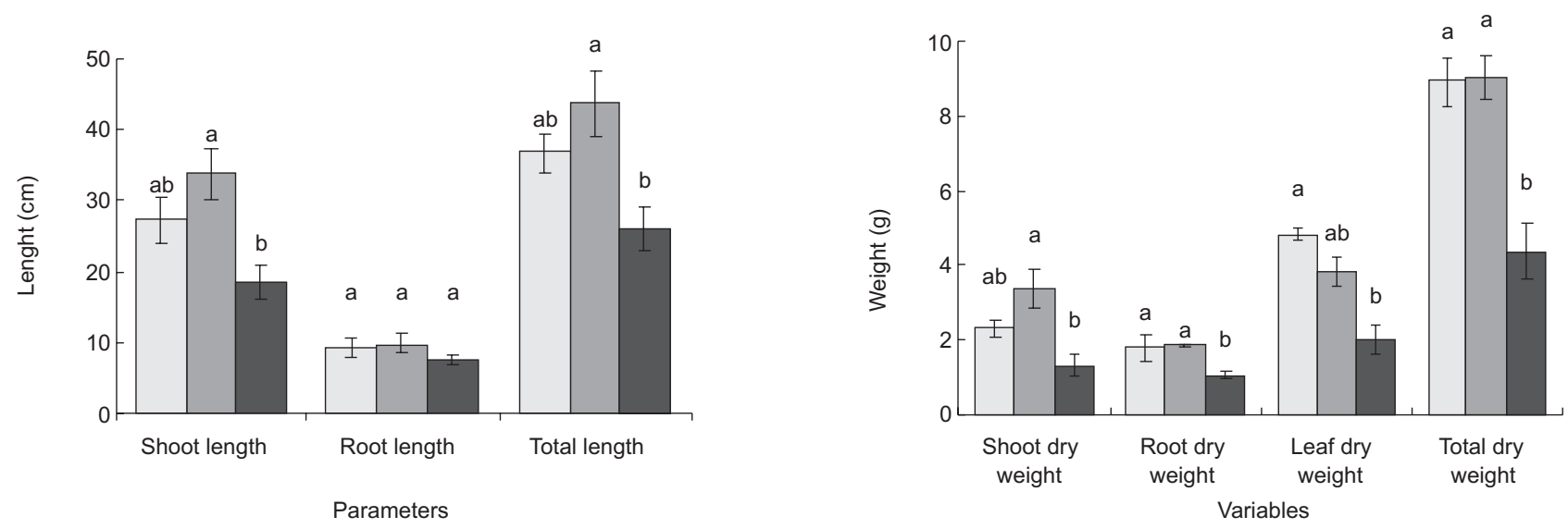

$\square$ FS $\quad \square$ PS $\quad \square$ DS

Fig. 8. Growth performance (height and dry mass) of seedlings grown in full sun(FS), partial shade (PS) and deep shade (DS) regimes

many studies. Ashton (1995), Whitmore and Brown (1996), Ashton et al. (1997), Barker et al. (1997) reported better growth of Dipterocarp seedlings in partial shade or in moderate light intensity. Growth of seedlings and saplings of Dipterocarp varies from moderate to very shade tolerant. In field trials, Dipterocarp growth rate and survival were consistently better in moderate light levels than the understory of either primary or secondary forest (Ang 1991; Adjers et al. 1995).

\section{Clonal propagation through stem cutting}

\section{Rooting percentage}

Rooting percentage in the cuttings was dramatically enhanced due the IBA concentrations in the treatments. The highest rooting percentage (63.7) was obtained in the cuttings treated with $0.8 \%$ IBA solution followed by $60 \%$ with $0.4 \%$ IBA and the lowest (20) with no IBA treatment (Fig. 9). Rooting percentage of cuttings gradually increased with the increasing concentration of rooting hormone IBA.
Application of rooting hormone IBA has been found to enhance the rooting percentage of cutting reported by several authors. Exogenous auxin ( $0.4 \%$ IBA) significantly enhanced the rooting percentage of cuttings of jackfruit (Hossain et al. 2002), Swietenia macrophylla and Chukrasia velutina (Hossain et al. 2004), Prunus africana (Tchoundjeu et al. 2002), Pausinystalia johimbe (Tchoundjeu et al. 2004), Baccaurea sapida (Abdullah et al. 2005), Stereospermum suaveolens (Baul et al. 2009), and of Flacourtia jangomas (Hossain et al. 2011). The concentration of applied IBA varied from species to species and also from the state of the cutting ranging from $0.1 \%$ to (Baul et al. 2011) to 1.0 $\%$ (Lee and Bilderback 1990). The result of our present study revealed that an IBA concentration of $0.8 \%$ was suitable for rooting of cuttings derived from the stockplants of $A$. scaphula seemed to be difficulty to root. However, Baul et al (2009) reported better rooting percentage in $S$. suaveolens cuttings with $0.4 \%$ IBA soultion. Similar result was also reported by Rosa and Dos (1997) for Sclerolobium paniculatum cuttings which rooted best with $0.4 \%$ IBA and worst 

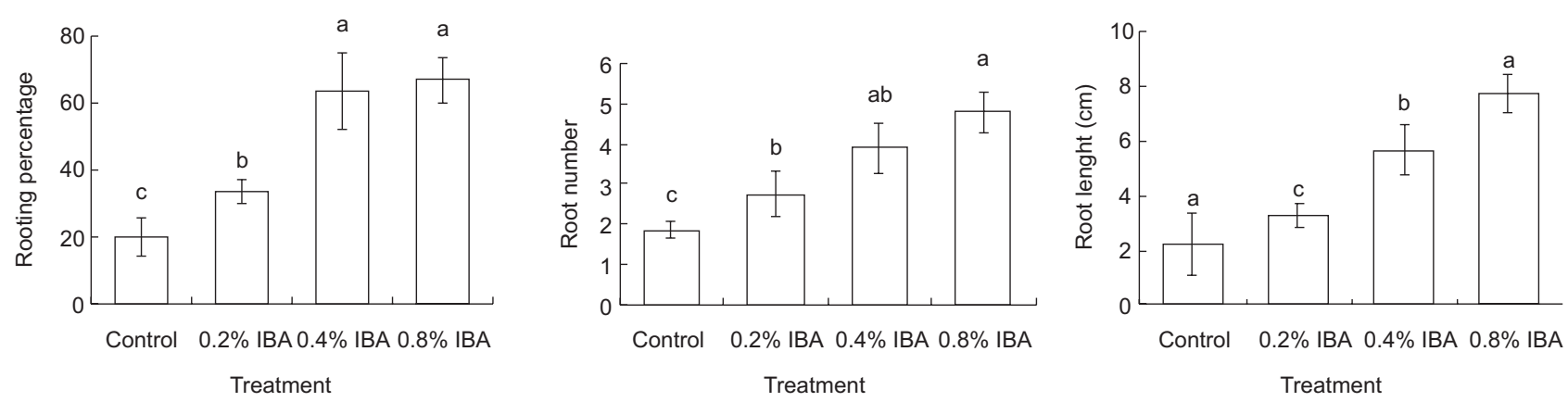

Fig. 9. Rooting percentage, root number and root length of cuttings treated with different concentrations of IBA solution. Note: The same letter(s) indicates no significant difference at $p \leq 0.05$, according to Duncan's Multiple Range Test. I (bar) indicates the standard error of means

in cuttings without any treatment (control). Applied IBA may have an indirect influence by enhancing the speed of translocation and movement of sugar to the base of cuttings and consequently stimulate rooting (Haissig 1974, 1982). Practically, speeding up the process of adventitious root formation is considered as an advantage, as the earlier the cuttings were able to form roots, the greater the chances for them to survive.

\section{Root number and root length}

Cuttings rooted 12 weeks after setting them in the rooting medium in propagator. Number of root developed per cutting of $A$. scaphula was enhanced by the rooting hormone IBA. Maximum average number of root (4.8) per cutting was observed in cuttings treated with $0.8 \%$ IBA followed by 3.8 with $0.4 \%$ IBA solution. The lowest number of root (1.8) was exhibited by the cuttings in control (Fig. 9, 10). Similar findings were reported from the experiments on Shorea leprosula cuttings which produced greater number of roots with IBA compared to the untreated cuttings (Hamzah et al. 1994).

The maximum length of root $(7.7 \mathrm{~cm})$ was observed in the cuttings treated with $0.8 \%$ IBA solution followed by 5.7 in the cuttings treated with $0.4 \%$ IBA

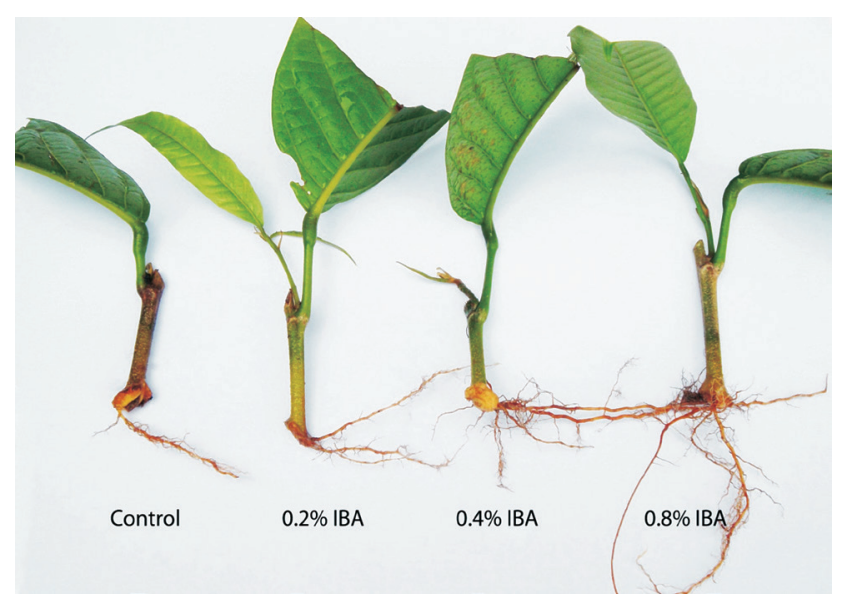

Fig. 10. Rooting in cuttings of $A$. scaphula treated with different concentration of IBA solution and the lowest (2.5) was recorded from the control (Fig. 9, 10). Aalm et al. (2007), and Hossain et al. $(2004,2011)$ also reported that the root formation and growth of shoot in cuttings increased significantly in presence of IBA. Kamaluddin et al. (1996) recorded significant increase both in the percentage of rooting and the number of roots with the application of IBA for Artocarpus heterophyllus. Again in a separate experiment Kamaluddin et al. (1998) found that auxin application significantly increased the rooting ability of Chickrassia velutina cuttings.

\section{Steckling capacity of rooted cuttings}

Significantly higher percentage of rooted cuttings survived in nursery condition when they were rooted with IBA treatment than those were in control. The highest survival percentage was 83.3 in the cuttings treated with $0.8 \%$ IBA followed by $0.4 \%$ and the lowest (52.2) was in control. The result was supported by Hossain et al. (2011) who obtained $85 \%$ survival in the $F$. jangomas cuttings treated with $0.4 \%$ IBA and lowest in control which was in the same line with the results of Nath and Barooah (1992). The maximum number of root per cutting developed with $0.8 \%$ or $0.4 \%$ IBA solution made the stecklings (rooted cutting) for better survival and growth potential in the nursery condition. However, there was no report found that discussed the factors affecting the survival percentage in the rooted cuttings of $A$. scaphula.

\section{Conclusion}

When seeds become scarce and recalcitrant like A. scaphula, special measures are required to enhance the regeneration capacity of the seeds and the overall performance of the seedlings. It is evident from this study that higher germination percentage was obtained from dewinged $A$. scaphula seeds than those from the winged. Dewinged seeds sown in horizontal or inverted orientation also showed better growth performance and produced well shaped seedlings. The seedlings grew better in partial shade regime 
compared to full sun or deep shade. Rooting ability of $A$. scaphula stem cuttings in respect of rooting percentage, root number and root length was highest in cuttings treated with $0.8 \%$ IBA followed by $0.4 \%$ IBA solution which proved their better survival potential in the nursery conditions. However, testing the growth performance of the seedlings or progenies from clonal propagation in the field was beyond the objectives of this study due to the time framework for the research project which appears to be one of the important components be investigated in the future.

\section{Acknowledgement}

This study was partly supported by a research grant from Inter-Cooperation-Swidish Development Cooperation, Bangladesh. The authors also extend their thanks to Dr. Mohammad Mahfuzur Rahman for his critical reviewing the manuscript prior to submission to the Journal and Mr. Reduwan, a graduate student of IFESCU for taking one of the photographs. We are also grateful to two anonymous reviewers for their critical comments on an earlier version of the manuscript.

\section{References}

Abdullah A.T.M., Hossain M.A., Bhuiyan M.K. 2005. Propagation of Latkan (Baccaurea sapida Muell. Arg.) by mature stem cutting. Research Journal of Agriculture and Biological Sciences 1: 129-134.

Adjers G., Hadengganan S., Kuusipalo J., Nuryanto K., Vesa L. 1995. Enrichment planting of dipterocarps in logged-over secondary forests: effect of width, direction and maintenance method of planting line on selected Shorea species. Forest Ecology and Management 73: 259-270.

Alam R., Rahman K., Ilyas M., Ibrahim M., Rauf M.A. 2007. Effect of indole butyric acid concentrations on the rooting of kiwi cuttings. Sarhad Journal of Agriculture 23: 293-295.

Ang L.H. 1991. Effects of open and under planting on early survival and growth of Endospermum malaccense (sesendok), Alstonia angustiloba (pulai) and Shorea parvifolia (meranti sarang punai). Journal of Tropical Forest Science 3: 380-384.

Ashton M.S. 1995. Seedling growth of occurring Shorea species in the simulated light environment of a rainforest. Forest Ecology and Management 72: 1-12.

Ashton P. 1998. Anisoptera scaphula. In.IUCN (2012) IUCN Red List of Threatened Species. Version 2012.2. (www.iucnredlist.org. Downloaded on 21 February 2013).

Ashton P.M.S., Gamage S., Gunatilleke I.A.U.N., Gunatilleke C.V.S. 1997. Restoration of a Sri Lankan rainforest: using Caribbean pine Pinus caribaea as a nurse for establishing late successional tree species. Journal of Applied Ecology 34: 915-925.

Ashton P.S. 2005. Dipterocarpaceae. In Soepadmo E, Saw LG, Chung RCK (eds.) Tree Flora of Sabah and Sarawak. Malaysia: FRIM. 63-388, 485-486, 495-498.

Bangladesh Bureau of Statistics (BBS) 2010. Statistical yearbook of Bangladesh, Statistics Division, Ministry of Planning, Government of the People's Republic of Bangladesh. p. xxii.

Banglapedia 2012. http://www.banglapedia.org. Accessed 10 January 2012.

Banik R.L. 1980. Studies on sowing position of garjan seeds on their germination and seedling behaviour. Bano Biggyan Patrika 9: 43-52.

Barker M.G., Press M.C., Brown N.D. 1997. Photosynthetic characteristics of dipterocarp seedlings in three tropical rain forest light environments: a basis for niche partitioning. Oecologia 112: 453463.

Baul T.K., Hossain M.M., Mezbahuddin M., Mohiuddin M. 2011. Vegetative propagation of Litsea monopetala, a wild tropical medicinal plant: Effects of indole-3-butyric acid (IBA) on stem cuttings. Journal of Forestry Research 22: 409-416.

Baul T.K., Mezbahuddin M., Mohiuddin M. 2009. Vegetative propagation and initial growth performance of Stereospermum suaveolens DC., a wild tropical tree species of medicinal value. New Forests 37: 275-283.

Bennet-Clarck T.A., Younis A.F., Esnault R. 1959. Geotropic behavior of roots. Journal of Experimental Botany 10: 69-86.

Bhat P.R. 2011. Effect of orientation of seed placement on seedling emergence in some species of Calamus. Advances in Bioresearch 2: 86-89.

Bosy J., Aarssen L.W. 1995. The effect of seed orientation on germination in a uniform environment differential success without genetic or environmental variation. Journal of Ecology 83: 769-773.

Chouffot-struycken B. 1986. Contribuition a l'etude des capacites de multiplication vegetative du Shorea curiisii Dyer ex King. Dipterocarpaceae de Malaisie. These de1' Universite Louis Pasteur. Strasbourg, $136 \mathrm{pp}$.

Das D.K., Alam M.K. 2001. Trees of Bangladesh. Bangladesh Forest Research Institute, Chittagong, Bangladesh. 324pp

Elfeel A.A. 2012. Effect of seed pre-treatment and sowing orientation on germination of Balanites aegyptiaca (L.) Del. seeds. American-Eurasian Journal of Agricultural and Environmental Sciences 12: 897-900.

FAO 2009. State of the world's forests 2009. FAO, Rome.

Fett-Neto A.G., Fett J.P., Goulart L.W.V., Pasquali G., Termignoni R.R., Ferreira A.G. 2001. Distinct ef- 
fect of auxin and light on adventitious root development in Eucalyptus saligna and Eucaliptus globules. Tree Physiology 21: 457-464.

Gunaga R.P., Doddabasava, Vasudeva R. 2011. Influence of seed size on germination and seedling growth in Mammea suriga. Karnataka Journal of Agricultural Sciences 24: 415-416.

Gunaga R.P., Hareesh T.S., Vasudeva R. 2007. Effect of fruit size on early seedling vigour and Biomass in White Dammer (Vateria indica): a vulnerable and economically important tree species of the Western Ghats. Journal of NTFPs 14: 197-200.

Haissig B.E. 1974. Influences of auxin synergists on adventitious root primordium initiation and development. New Zealand Journal of Forestry Science 4: 311-323.

Haissig B.E. 1982. Carbohydrate and amino acid concentrations during adventitious root primordium development in Pinus banksiana Lamb. cuttings. Forest Science 28: 813-821.

Halle F., Hanif-Kamil 1981. Vegetative propagation of dipterocarps by stem cuttings and airlayering. The Malaysian Forester 44: 314-318.

Hamzah A. 1990a. A note on the rooting of Shorea bracleolata stem cuttings. Journal of Tropical Forest Sciences 3: 187-188.

Hamzah A. 1990b. A note on growth behaviour of branch cuttings of Hopea odorata. Journal of Tropical Forest Sciences 3: 303-305.

Hamzah A. 1990c. A note on the effect of leaf number on rooting of Hopea, odorata stem cuttings. Journal of Tropical Forest Sciences 3: 384-386.

Hamzah A., Dick J. Mc. P., Leakey R.R.B., Gracec J., Smith R.I. 1994. Effect of indole butyric acid (IBA) on stem cuttings of Shorea leprosula. Forest Ecology and Management 72: 199-206.

Hossain M.A., Islam M.A., Hossain M.M. 2004. Rooting ability of cuttings of Swietenia macrophylla King and Chukrasia velutina Wight et Arn. as influencedby exogenous hormone. International Journal of Agriculture and Biology 6: 560-564.

Hossain M.A., Kamaluddin, M. 2004. Effects of lateral shading on growth and morphology of shoots and rooting ability of Jackfruit (Artocarpus heterophyllus Lam.) cuttings. Journal of Applied Horticulture 6: 35-38.

Hossain M.A., Kamaluddin M. 2005. Lateral shading of stock plants enhances rooting performance of guava (Psidium guajava L.) cuttings. Journal of Applied Horticulture 7: 51-56.

Hossain M.A., Rahman M.M., Kamaluddin M. 2002. Rooting ability of cuttings as influenced by etiolation of stockplants and auxin. SUST Studies 4: $55-65$

Hossain M.A., Sen M., Jewel M.I.U., Kabir M.A. 2011. Propagation of Flacourtia jangomas: an approach to- wards the domestication of a wild fruit species in Bangladesh. Dendrobiology 65: 63-71.

IUCN 2012. The IUCN Red List of Threatened Species. Version 2012.2. (http://www.iucnredlist. org/details/33006/0). Accessed on 21 February, 2013.

Kamaluddin M. 1996. Clonal Propagation of Eucalyptus and Acacia hybrid by stem cuttings. Research Report. Forestry Division, Bangladesh Agricultural Research Council. Dhaka. 31pp.

Kamaluddin M. 1988. Current status of clonal forestry in the tropics and its potential application in Bangladesh. Dissertation for Master of Science in Resource Management. University of Edinburgh, United Kingdom. 74pp

Kamaluddin M., Ali M., Bhuiyan M.K. 1996. Effect of auxin, rootability of cuttings and growth of stecklings of Jackfruit (Artocarpus heterophyllus Lam.). Chittagong University Studies Part II. 20: 71-75.

Kamaluddin M., Miah M.E., Pandit S. 1998. Propagation of Chickrassia velutina by cutting: response to applied auxin and shoot production. Malaysian Forester 61: 92-100.

Kantarali M. 1993a. Vegetative Propagation of Hopea odorata by Cuttings: a Loin-Cost Technology. Technical Publication No. 16. ASEAN-Canada Forest Tree Seed Centre Project, Saraburi. 7pp.

Kantarali M. 1993 b. Vegetative Propagation of Dipterocarps by Cuttings in ASEAN Region. Review Paper No. 1. ASEAN-Canada Forest Tree Seed Centre Project, Saraburi. 58 pp.

Krishnapillay B., Tompsett P.B. 1998. Seed handling. In., Appanah S. and Turnbull, J M. (eds.), A Review of Dipterocarps - Taxonomy, Ecology and Silviculture. Centre for International Forestry Research, Bogor. 220 pp

Laurie M.V. 1940. Notes on germination of Scaphula (Anisoptera) glabra. Indian Forester 66: 653-654.

Lee C.C., Bilderback T.E. 1990. Propagation of Heptacodium jasminoides Airy-Shaw by softwood and semi-hardwood cuttings. Journal of Environment and Horticulture 8: 121-123.

Nath J.C., Barooah S. 1992. Propagation of some minor fruits of Assam by rooting of stem cuttings. Horticulture Journal 5: 109-113.

Pandey A.K., Khatoon S. 1999. Effect of orientation of seed placement and depth of sowing on seedling emergence in Sterculia urens Roxb. Indian Forester 125: 720-724.

Prasad P., Nautiyal A.R. 2003. Effect of orientation of seed placement in soil on seedling emergence in two Bauhinia species Bauhinia vahlii Wight et. Arn. and Bauhinia racemosa Lam. Seed Science and Technology 31: 497-503.

Rosa L., Dos S. 1997. Promotion of rooting in stem cuttings of Tachi-branco (Sclerolobium paniculatum Vogel) by application of different concentrations 
of indole-3-butyric acid. Boletim da Faculdade de Ciencies Agraries do Para 28: 81-91.

Sattar M.A., Akhtaruzzaman A.F.M. 1997. End use classification of lesser used or unused wood species. Bull. no. 1 (Forest Products Branch). Bangladesh Forest Research Institute, Chittagong

Smits W.T.M. 1983. Vegetative propagation of Shorea cf robtusa and Agathis dammara by means of leaf-cuttings and stem-cuttings. Malaysian Forester 46: 175-185.

Smits W.T.M. 1986. Vegetative propagation and possibilities for its use with Dipterocarpaceae. In Wirakusumah, S. (Ed.). Disckusi Tebalas Beberapa Aspek Pembangunan Hulan. Menelusuri Cara-Cara Inovatif Reboisasi di Indonesia, Jakarta. Inhutani I. 8 pp.
Tchoundjeu Z., Avana M.L., Leakey R.R.B., Simons A.J., Asaah E., Duguma B., Bell J.M. 2002. Vegetative propagation of Prunus africana: effects of rooting medium, auxin concentrations and leaf area. Agroforestry System 54: 183-192.

Tchoundjeu Z., Mpeck M.L.N., Asaah E., Amougou A. 2004. The role of vegetative propagation in the domestication of Pausinystalia johimbe (K. Schum), a highly threatened medicinal species of West and Central Africa. Forest Ecology and Management 188: 175-183.

Whitmore T.C., Brown N.D. 1996. Dipterocarp seedling growth in rain forest canopy gaps during sixand-half years. Philosophical Transaction of Royal Society London 351: 1195-1203. 
Towards the propagation of a critically endangered tree species Anisoptera scaphula

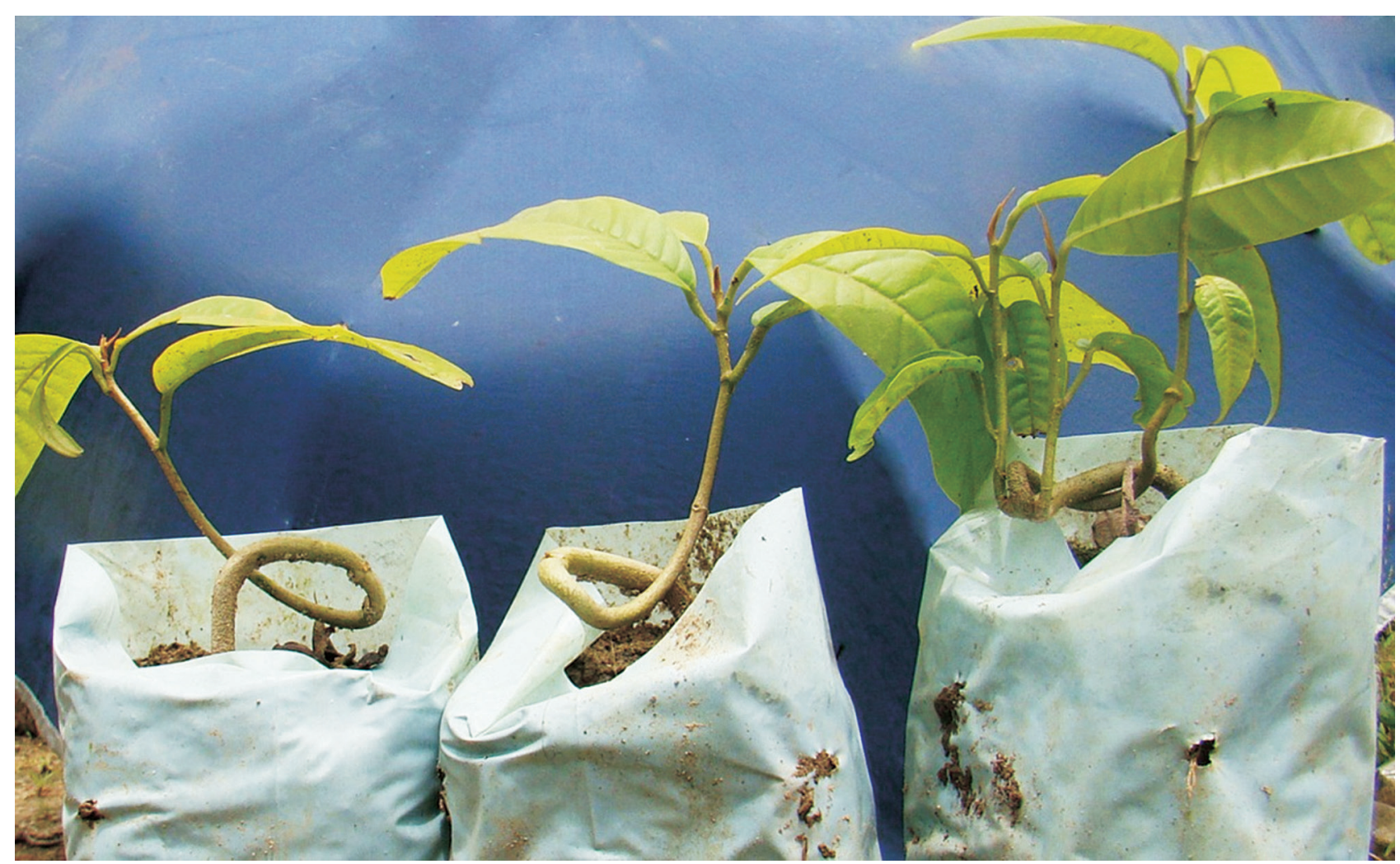

Supplementary data 1. Deformed seedlings grown from the winged or dewinged seeds sown vertically with full buried position 